\title{
Pengungkapan Tanggung Jawab Sosial Memoderasi Pengaruh Profitabilitas dan Ukuran Perusahaan pada Nilai Perusahaan
}

\author{
Ni Kadek Dona Puspita Dewi ${ }^{1}$ \\ I Made Mertha ${ }^{2}$ \\ ${ }^{1}$ Fakultas Ekonomi dan Bisnis Universitas Udayana (Unud), Bali, Indonesia \\ email: donapuspitadewi@gmail.com/Tlp: +6282247942747 \\ ${ }^{2}$ Fakultas Ekonomi dan Bisnis Universitas Udayana (Unud), Bali, Indonesia
}

\begin{abstract}
ABSTRAK
Penelitian ini bertujuan untuk mendapatkan bukti empiris mengenai pengaruh profitabilitas dan ukuran perusahaan pada nilai perusahaan dengan pengungkapan tanggung jawab sosial sebagai variabel moderasi. Penelitian ini dilakukan pada perusahaan sektor makanan dan minuman yang terdaftar di BEI tahun 2013-2016. Jumlah sampel yang diambil sebanyak 11 perusahaan, dengan metode purposive sampling. Metode pengumpulan data dalam penelitian ini adalah observasi non partisipan. Teknik analisis data yang digunakan adalah Moderated Regression Analysis. Berdasarkan hasil analisis ditemukan bahwa profitabilitas berpengaruh signifikan positif pada nilai perusahaan. Ukuran perusahaan berpengaruh signifikan positif pada nilai perusahaan. Pengungkapan tanggung jawab sosial memperlemah pengaruh profitabilitas pada nilai perusahaan. Pengungkapan tanggung jawab sosial memperkuat pengaruh ukuran perusahaan pada nilai perusahaan.

Kata kunci: Profitabilitas, ukuran perusahaan, pengungkapan tanggung jawab sosial, nilai perusahaan

\section{ABSTRACT}

This study is aimed to find empirical evidence concerning the effect of profitability and company size on the company value in which social responsibility disclosure is used as the moderating variables. This study was conducted on the food and beverage companies which were listed in Indonesian Stock Exchange during 2013-2016 periods. There are 11 companies used as the sample by using purposive sampling method. Non-participantmethod was used as the method of collecting data while Moderated Regression Analysis technique was used as the technique of analyzing data. Based on the analysis, it was found that both profitability and company size brought positive effect on the company value. Social responsibility disclosure weakened the effect of profitability on the company value. Meanwhile, it strengthened the effect caused by the company size.

Keywords: Profitability, company size, social responsibility disclosure, company value
\end{abstract}

\section{PENDAHULUAN}

Memasuki Masyarakat Ekonomi Asean (MEA) atau ASEAN Economic Community (ACC) yang telah diberlakukan dari tahun 2015 memberikan tantangan tersendiri terhadap industri pasar modal di Indonesia. Hal ini mengharuskan industri pasar modal di Indonesia dituntut untuk lebih siap guna memenangi pangsa pasar di Asia karena akan terjadi persaingan yang semakin ketat dari sebelumnya. Ketatnya persaingan bisnis dan meningkatnya tingkat 
Ni Kadek Dona Puspita Dewi dan I Made Mertha. Penungkapan...

kejelian investor mengharuskan perusahaan untuk berlomba-lomba meningkatkan nilai perusahaan. Nilai perusahaan sangat penting untuk dijadikan sebagai salah satu pertimbangan investor sebelum memutuskan untuk melakukan investasi. Tingginya nilai suatu perusahaan dapat menaikkan tingkat kemakmuran pemegang saham perusahaan, sehingga para pemegang saham akan menanamkan modal di perusahaan tersebut (Haruman, 2008). Investor akan percaya pada prospek perusahaan jika perusahaan memiliki nilai perusahaan yang tinggi. Nilai perusahaan menjadi sangat penting karena dapat menggambarkan kinerja perusahaan dimana pada akhirnya dapat memengaruhi persepsi investor terhadap perusahaan. Armika (2017) menyatakan sebelum melakukan investasi pada perusahaan, investor perlu mengetahui nilai perusahaan itu.

Penting bagi sebuah perusahaan untuk mengetahui apa saja faktor yang dapat memengaruhi nilai perusahaan dalam usaha untuk meningkatkan nilai perusahaan. Analisa (2011) mengungkapkan bahwa besar kecilnya profitabilitas yang dihasilkan oleh perusahaan dapat memengaruhi nilai perusahaan. Tujuan investor berinvestasi pada perusahaan adalah untuk memperoleh return berupa dividen atau capital gain. Perusahaan dengan profitabilitas yang semakin tinggi akan memberikan peluang return yang lebih tinggi pula bagi para investor. Profitabilitas yang tinggi menunjukkan prospek perusahaan yang baik, sehingga investor akan merespon positif sinyal tersebut dan pada akhirnya dapat meningkatkan nilai perusahaan.

Nilai perusahaan juga dapat dipengaruhi oleh ukuran perusahaan selain dipengaruhi oleh rasio profitabilitas. Hasil penelitian Gill dan Obradovich (2012) 
menunjukkan jika ukuran perusahaan dapat memberi pengaruh positif dan signifikan pada nilai perusahaan. Analisa (2011) menyatakan bagi perusahaan yang akan go public nilai perusahaan dapat diindikasikan atau tersirat dari jumlah variabel yang melekat pada perusahaan tersebut, seperti aset yang dimiliki dan keahlian manajemen dalam mengelola perusahaan. Ketersediaan banyak aset yang dimiliki perusahaan akan memberikan keleluasaan kepada manajer pengelola dana untuk menggunakannya secara optimal. Penggunaan aset yang optimal ini diharapkan dapat meningkatkan nilai perusahaan.

Terdapat banyak penelitian sebelumnya mengenai pengaruh profitabilitas dan ukuran perusahaan pada nilai perusahaan. Penelitian tersebut mendapatkan hasil yang inkonsisten. Penelitian yang dilakukan oleh Ayu dan Suarjaya (2017), Widhiastuti dan Latrini (2015) dan juga Purwaningsih dan Wirajaya (2014) menemukan hasil bahwa ROA berpengaruh terhadap nilai perusahaan. Berbeda dengan penelitian dari Susianti dan Yasa (2013) yang mendapatkan hasil berbeda yaitu ROA tidak berpengaruh positif dan signifikan terhadap nilai perusahaan. Penelitian yang dilakukan oleh Gill dan Obradovich (2012), Kusumayanti dan Astika (2016) dan juga Raharja dan Putra (2016) yang menemukan bahwa ukuran perusahaan berpengaruh positif terhadap nilai perusahaan. Hasil penelitian ini tidak didukung oleh penelitian yang dilakukan oleh Gill dan Marthur (2011) yang mendapatkan hasil bahwa ukuran perusahaan tidak dapat memberi pengaruh positif pada nilai perusahaan. Hasil penelitian yang inkonsisten ini mendukung penulis untuk meneliti lagi pengaruh antara variabel-variabel yang sama dengan menggunakan pengungkapan tanggung jawab sosial sebagai variabel moderasi 
Ni Kadek Dona Puspita Dewi dan I Made Mertha. Penungkapan...

yang diduga dapat memberikan pengaruh yang memperkuat atau memperlemah hubungan variabel bebas dengan variabel terikat.

Sekarang ini investor memakai strategi investasi yang secara eksplisit menggunakan pertimbangan dengan kriteria kinerja CSR selain ukuran financial (Elliot et al., 2011). Perusahaan yang percaya pada keberadaan jangka panjang perusahaan tidak hanya dilihat dari kinerja keuangannya saja namun juga pada kinerjanya pada lingkungan sosial (Aghashahi et al., 2013). Melalui pengungkapan tanggung jawab sosial diharapkan perusahaan mendapatkan legitimasi dari masyarakat yang berdampak pada kelangsungan hidup perusahaan. Undang-Undang No. 40 Tahun 2007 tentang Perseroan Terbatas mengatur mengenai kewajiban perusahaan dalam pelaksanaan dan mengungkapkan aktivitas tanggung jawab sosial perusahaan membuktikan jika pemerintah juga menyadari pentingnya pengungkapan tanggung jawab sosial. Menimbang untuk melaksanakannya ketentuan Pasal 74 ayat (4) Undang-Undang No. 40 Tahun 2007 dikeluarkan juga Peraturan Pemerintah Republik Indonesia No.47 tahun 2012 tentang Tanggung Jawab Sosial dan Lingkungan Perseroan Terbatas. Setiap investor juga diwajibkan untuk bersama-sama dalam tanggung jawab sosial perusahaan yang diatur dalam UU Penanaman Modal No. 25 Tahun 2007.

Objek yang akan digunakan dalam penelitian ini adalah perusahaan pada sektor makanan dan minuman yang terdaftar di Bursa Efek Indonesia (BEI). Dapat dilihat dalam Grafik 1 bahwa pertumbuhan industri sektor makanan dan minuman dari tahun 2013-2016 menunjukkan adanya pertumbuhan yang positif, 
meskipun pada tahun 2015 terjadi penurunan namun bukan merupakan pertumbuhan yang negatif.

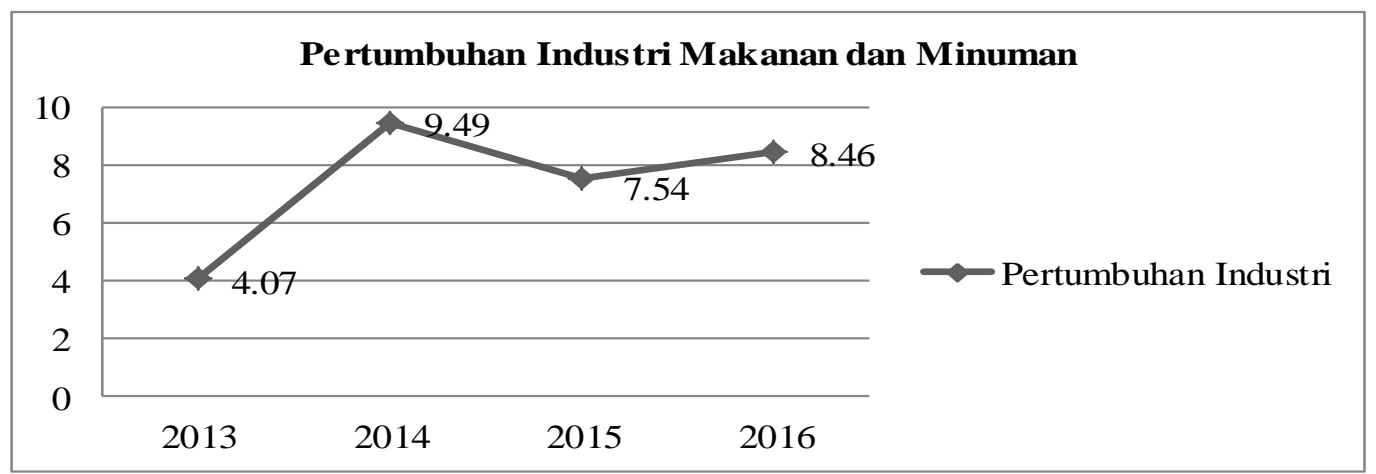

Gambar 1.

Pertumbuhan Industri Makanan dan Minuman Tahun 2013-2016 Sumber: Data diolah, 2017

Pertumbuhan positif yang selalu dialami ini menjadikannya sektor yang berperan sebagai penggerak perekonomian. Pertimbangan lainnya yaitu saham pada sektor makanan dan minuman banyak diminati oleh investor karena saham pada sektor ini bersifat non siklikal artinya tidak bersifat musiman. Industri makanan dan minuman merupakan salah satu sektor usaha yang terus mengalami pertumbuhan. Seiring dengan meningkatnya pertumbuhan jumlah penduduk di Indonesia, volume kebutuhan terhadap makanan dan minuman pun terus meningkat.

Tujuan penelitian ini adalah untuk memperoleh bukti empiris pengaruh profitabilitas dan ukuran perusahaan pada nilai perusahaan, dan untuk memperoleh bukti empiris pengungkapan tanggung jawab sosial dalam memoderasi pengaruh profitabilitas dan ukuran perusahaan pada nilai perusahaan. Manfaat yang dapat diberikan yaitu manfaat teoretis dimana diharapkan dapat memberikan bukti empiris mengenai pengungkapan tanggung jawab sosial dalam memoderasi pengaruh 
Ni Kadek Dona Puspita Dewi dan I Made Mertha. Penungkapan...

profitabilitas dan ukuran perusahaan pada nilai perusahaan. Manfaat praktis yang diharapkan yaitu penelitian ini dapat memberikan informasi yang berguna untuk perusahaan sebagai suatu bahan pertimbangan pengambilan keputusan dalam upaya mengoptimalkan nilai perusahaan, dan informasi kepada para investor dalam menilai perusahaan sebagai bahan pertimbangan dalam mengambil keputusan berinvestasi.

Teori stakeholder mengisyaratkan dimana operasi perusahaan harus dapat memberi kontribusi kepada stakeholder-nya. Perusahaan harus memperhatikan stakeholder-nya karena dapat mempengaruhi aktivitas dan kebijakan perusahaan. Dwipayadnya dkk., (2015) mengungkapkan perusahaan penting untuk mempertahankan relasi yang positif dengan stakeholder untuk menjaga stabilitas perusahaan demi kelangsungan hidup jangka panjang perusahaan.

Teori legitimasi mendorong perusahaan untuk melakukan pengungkapan sukarela sebagai salah satu bentuk pertanggungjawaban terhadap kontrak sosial yang dimiliki antara perusahaan dengan komunitas disekitarnya (Guthrie et al., 2004). Barkemeyer (2007) menyatakan bahwa pengungkapan tanggung jawab sosial perusahaan dilakukan untuk mendapatkan nilai positif dan legitimasi dari masyarakat. Pengungkapan aktivitas CSR akan menunjukkan tingkat kepatuhan suatu perusahaan seperti kepatuhan terhadap norma-norma yang berlaku, serta harapan-harapan publik kepada perusahaan tersebut (Branco dan Rodrigues, 2008).

Teori sinyal mengemukakan tentang bagaimana seharusnya perusahaan memberikan sinyal kepada pengguna laporan keuangan. Suatu informasi yang 
dipublikasikan sebagai sebuah pengumuman akan memberikan sinyal bagi investor untuk mengambil keputusan investasi (Jogiyanto, 2013:517). Sinyal yang diberikan merupakan sebuah promosi atau informasi yang menunjukkan keunggulan perusahaan tersebut.

Menurut Mulyadi dan Anwar (2012), tanggung jawab sosial adalah tanggung jawab suatu perusahaan kepada stakeholder untuk tujuan pembangunan berkelanjutan perusahaan. Pengungkapan tanggung jawab sosial penting untuk dilakukan karena melalui pengungkapan lingkungan hidup pada laporan tahunan perusahaan, masyarakat dapat memantau aktivitas yang dilakukan oleh perusahaan dalam rangka memenuhi tanggung jawab sosialnya. Tujuan dilakukannya kegiatan tanggung jawab sosial oleh perusahaan demi untuk peningkatan penjualan perusahaan dan peningkatan citra yang positif di hadapan investor (Mukhtaruddin et al., 2014).

Profitabilitas menjadi perhatian utama para investor karena tujuan didirikannya suatu perusahaan adalah untuk memperoleh laba. Profitabilitas dimaksudkan untuk mengukur efisiensi atas penggunaan aktiva perusahaan atau mungkin juga efisiensi yang dikaitkan dengan penjualan yang berhasil diciptakan, sehingga profitabilitas ini dapat dikatakan sebagai ukuran tingkat efektifitas manajemen suatu perusahaan. Investasi yang dilakukan oleh pemegang saham bertujuan untuk memperoleh return. Semakin tinggi profitabilitas perusahaan akan memperbesar peluang pemegang saham untuk memperoleh return sehingga dapat meningkatkan nilai perusahaan (Ratih dan Damayanthi, 2016). Profitabilitas dalam penelitian ini diproksikan melalui Return On Asset (ROA). 
Ni Kadek Dona Puspita Dewi dan I Made Mertha. Penungkapan...

ROA merupakan pengukuran kemampuan perusahaan secara keseluruhan di dalam menghasilkan keuntungan dengan jumlah keseluruhan aktiva yang tersedia di dalam perusahaan. Semakin besar ROA suatu perusahaan maka semakin besar tingkat keuntungan yang dicapai perusahaan tersebut dan semakin baik pula posisi perusahaan tersebut dari segi penggunaan aset.

Ukuran perusahaan dapat menunjukkan total aset yang dimiliki oleh perusahaan, semakin besar ukuran perusahaan maka semakin besar pula aset yang dimiliki oleh perusahaan. Ukuran suatu perusahaan dapat memengaruhi kebijakan manajemen perusahaan dalam mengambil sebuah keputusan pendanaan perusahaan. Keputusan pendanaan yang akan dipakai oleh perusahaan harus bisa menguntungkan perusahaan dalam rangka meningkatkan nilai perusahaan.

Nilai perusahaan merupakan pandangan investor atas keberhasilan yang dicapai perusahaan dalam mengelola sumber daya yang dimilikinya, yang tercermin melalui tingginya harga pasar saham perusahaan (Sujoko dan Soebiantoro, 2007). Brigham (2007:11) juga menyatakan berbagai kebijakan diambil oleh manajemen dalam upaya meningkatkan nilai perusahaan melalui peningkatan kemakmuran pemilik dan pemegang saham tercermin pada harga saham. Tinggi rendahnya harga saham suatu perusahaan menunjukkan bagaimana publik menilai kinerja perusahaan. Harga saham yang tinggi mencerminkan tinggi pula nilai suatu perusahaan. Pratiwi (2017) menyatakan nilai perusahaan yang tinggi akan membuat pasar percaya akan kinerja perusahaan saat ini dan juga prospek perusahaan di masa yang akan datang. Dalam penelitian ini, nilai perusahaan diukur dengan pendekatan market value yaitu Tobin's Q. Rasio ini 
dapat menyampaikan informasi yang paling baik karena memasukkan seluruh aktiva perusahaan termasuk hutang dan modal yang dimiliki perusahaan.

Tujuan perusahaan dalam meningkatkan laba perusahaan dan memaksimumkan nilai perusahaan merupakan dua hal yang saling berkaitan dalam upaya meningkatkan kesejahteraan pemegang saham, dimana tujuan tersebut merupakan suatu kriteria penting dalam menjamin kelangsungan hidup perusahaan. Sujoko dan Soebiantoro (2007) mengatakan jika profitabilitas yang tinggi sebuah perusahaan adalah sinyal jika perusahaan memiliki peluang yang baik kedepannya. Hal ini akan dapat meningkatkan nilai sebuah perusahaan.

$\mathrm{H}_{1}$ : Profitabilitas berpengaruh pada nilai perusahaan.

Ukuran perusahaan merupakan salah satu acuan dalam menilai kinerja perusahaan. Ukuran perusahaan yang besar menunjukkan bahwa perusahaan mengalami perkembangan, sehingga investor akan secara positif dan nilai perusahaan pun akan meningkat (Sujoko dan Soebiantoro, 2007). Berdasarkan pernyataan tersebut, dapat disimpulkan bahwa investor akan cenderung memperhatikan perusahaan yang semakin besar ukurannya.

$\mathrm{H}_{2}$ : Ukuran perusahaan berpengaruh pada nilai perusahaan.

Teori sinyal menyatakan mengenai dorongan perusahaan untuk memberikan informasi kepada pihak eksternal dengan tujuan untuk meningkatkan nilai perusahaan (Retno, 2012). Teori stakeholder berpandangan bahwa perusahaan harus melakukan pengungkapan sosial sebagai salah satu tanggung jawab kepada para stakeholder. Kaur (2015) menyatakan jika tanggung jawab sosial yang dilakukan perusahaan adalah sinyal yang positif dimana dapat 
Ni Kadek Dona Puspita Dewi dan I Made Mertha. Penungkapan...

memberikan keuntungan finansial perusahaan itu sendiri. Gamerschlag et al., (2011) berpendapat dimana faktor yang mendorong manajemen untuk mengungkapkan informasi tanggung jawab sosialnya yang lebih luas salah satunya yaitu profitabilitas. Semakin baik tanggung jawab sosial yang dilakukan perusahaan didalam memperbaiki lingkungannya, maka nilai perusahaan semakin meningkat sebagai akibat dari para investor yang menanamkan sahamnya pada perusahaan.

$\mathrm{H}_{3}$ : Pengungkapan tanggung jawab sosial berpengaruh terhadap hubungan profitabilitas pada nilai perusahaan.

Pengungkapan tanggung jawab sosial perusahaan akan semakin luas seiring dengan besarnya aset yang dimiliki oleh perusahaan. Menurut Yao et al., (2011) perusahaan yang ukurannya semakin besar keberadaanya lebih disadari oleh stakeholder. Keadaan ini mengharuskan perusahaan untuk berusaha mendapatkan legitimasi dari stakehokder-nya. Untuk itu perusahaan dengan ukuran besar akan berusaha meningkatkan citra dengan memerhatikan lingkungan sosialnya. Perusahaan yang lebih memerhatikan lingkungan sosialnya dapat menarik minat para investor sehingga akan dapat menaikkan nilai perusahaan.

$\mathrm{H}_{4}$ : Pengungkapan tanggung jawab sosial berpengaruh terhadap hubungan ukuran perusahaan pada nilai perusahaan.

\section{METODE PENELITIAN}

Ruang lingkup penelitian ini adalah perusahaan makanan dan minuman yang terdaftar di Bursa Efek Indonesia tahun 2013-2016. Penelitian ini menggunakan data kualitatif yaitu nama perusahaan makanan dan minuman yang terdaftar di 
Bursa Efek Indonesia (BEI) tahun 2013-2016 dan data kuantitatif yaitu laporan keuangan dan laporan tahunan perusahaan sektor makanan dan minuman yang tercatat di BEI tahun 2013-2016. Sumber data yang pakai pada penelitian ini adalah data sekunder yang berasal dari laporan keuangan dan laporan tahunan perusahaan pada sektor makanan dan minuman yang tercatat di BEI tahun 20132016 yang telah dipublikasikan. Perolehan data penelitian melalui website resmi BEI.

Penelitian ini menggunakan pendekatan kuantitatif dengan desain penelitian asosiatif yaitu suatu penelitian yang dilakukan untuk mencari hubungan antara satu variabel dengan variabel yang lainnya. Penelitian ini menguji pengaruh profitabilitas dan ukuran perusahaan pada nilai perusahaan dengan pengungkapan tanggung jawab sosial sebagai variabel moderasi. Profitabilitas menggunakan proksi return on asset (ROA), ukuran perusahaan menggunakan proksi log total aset, pengungkapan tanggung jawab sosial menggunakan proksi CSRDI, sedangkan nilai perusahaan menggunakan proksi Tobin's Q.

Adapun variabel dependen pada penelitian ini yaitu nilai perusahaan, variabel independen yaitu profitabilitas dan ukuran perusahaan, dan variabel moderasinya yaitu pengungkapan tanggung jawab sosial. Nilai perusahaan diproksikan dengan Tobin's Q. Menurut Smithers dan Wright (2000) perhitungan Tobin's Q menggunakan rumus sebagai berikut:

$\mathrm{Q}=\frac{(E M V+D)}{(E B V+D)}$

Dimana:

$\mathrm{Q} \quad=$ Nilai perusahaan

$\mathrm{EMV}=$ Nilai pasar ekuitas (closing price $\times$ jumlah saham yang beredar) 
Ni Kadek Dona Puspita Dewi dan I Made Mertha. Penungkapan...

EBV = Nilai buku dari total ekuitas (total aktiva - total hutang)

$\mathrm{D} \quad=$ Nilai buku dari total hutang

Profitabilitas dalam penelitian ini diproksikan melalui return on asset (ROA) yang didapatkan dari laporan keuangan tahunan perusahaan makanan dan minuman selama periode penelitian. ROA merupakan pengukuran kemampuan perusahaan secara keseluruhan di dalam menghasilkan keuntungan dengan jumlah seluruh aktiva yang tersedia di dalam perusahaan. Rumus yang digunakan untuk mengukur ROA (Wiagustini, 2010:81) adalah sebagai berikut:

$R O A=\frac{\text { laba bersih }}{\text { total aktiva }} \times 100 \%$

Ukuran perusahaan adalah gambaran besar atau kecilnya suatu perusahaan yang dilihat berdasarkan ukuran nominal. Ukuran perusahaan dapat dinilai dengan Log dari total aset (Kusumayanti dan Astika, 2016 ).

Ukuran perusahaan $=\log ($ total aset $)$

Pengukuran tingkat pengungkapan tanggung jawab sosial perusahaan memakai data CSR yang diungkapkan pada annual report perusahaan. Pengukuran CSR mengacu pada Corporate Social Responsibility Disclosure Index (CSRDI) berdasarkan Global Reporting Initiative. Standar GRI G4 merupakan versi paling baru, dimana dapat dihitung dengan cara berikut :

$\mathrm{CSRDI}_{\mathrm{j}}=\frac{\sum X i j}{n}$

Keterangan:

$\mathrm{CSRDI}_{\mathrm{j}}=$ Corporate Social Responsibility Disclosure Index

$\sum \mathrm{X}_{\mathrm{ij}} \quad=$ Jumlah pengungkapan

$\mathrm{N} \quad=$ Item pengungkapan CSRDI 
Populasi dalam penelitian ini adalah seluruh perusahaan makanan dan minuman yang terdaftar di Bursa Efek Indonesia (BEI) periode tahun 2013-2016. Total perusahaan makanan dan minuman sampai tahun 2016 adalah 11 perusahaan. Sampel pada penelitian ini ditentukan menggunakan metode non probability sampling. Penelitian ini menggunakan purposive sampling yaitu pemilihan sampel berdasarkan pada kriteria dan sistematika tertentu yang telah ditetapkan sebelumnya. Kriteria-kriteria yang digunakan yaitu perusahaan makanan dan minuman yang terdaftar di BEI yang mempublikasikan laporan tahunan, menyajikan pengungkapan tanggung jawab sosial pada laporan tahunan dan perusahaan tidak mengalami kerugian selama periode pengamatan.

Penelitian ini menggunakan uji statistik deskriptif yang dapat memberikan gambaran atau deskripsi suatu data yang dilihat dari nilai rata-rata (mean), maksimum dan minimum (Ghozali, 2016:19). Model regresi yang baik jika model tersebut terbebas dari asumsi klasik statistik. Penelitian ini menggunakan empat uji asumsi klasik yaitu uji normalitas, multikolinearitas, autokorelasi dan heteroskedastisitas. Uji normalitas membandingkan antara tingkat signifikansi yang diperoleh dengan tingkat $\alpha$ yang digunakan yaitu 5 persen. Data berdistribusi normal apabila Asymp.sig (2-tailed) $>\alpha$ (Ghozali, 2016:160). Uji multikolinearitas dilakukan untuk mengetahui apakah terdapat korelasi antar variabel bebas di dalam model regresi. Pengujian ini ditentukan oleh nilai tolerance atau Variance Inflation Factor (VIF), jika nilai tolerance lebih dari atau sama dengan $10 \%(\geq 0,10)$ atau nilai Variance Inflation Factor (VIF) kurang dari atau sama dengan $10(\leq 10)$, maka tidak terjadi multikolinearitas (Ghozali, 
Ni Kadek Dona Puspita Dewi dan I Made Mertha. Penungkapan...

2016:103). Uji autokorelasi dilakukan dengan program SPSS menggunakan uji Durbin-Watson atau d statistik, tujuannya adalah untuk mengetahui adanya korelasi yang terjadi di antara anggota-anggota dari serangkaian pengamatan yang tersusun. Model regresi tidak terdapat autokorelasi apabila nilai Durbin-Watson lebih besar dari batas atas $\left(d_{u}\right)$ dan kurang dari 4- $d_{u}$. Uji heteroskedastisitas menggunakan uji Glejtser tujuannya untuk menguji apakah dalam model regresi terjadi ketidaksamaan variance dari residual satu pengamatan ke pengamatan yang lain.

Setelah dilakukan pengujian asumsi klasik dilakukan analisis data. Variabel moderasi dapat diketahui dengan melakukan uji Moderated Regression Analysis (MRA). Langkah-langkah pengujiannya yaitu perumusan model regresi, uji koefisien determinasi $\mathrm{R}^{2}$, uji kelayakan model (uji F) dan pengujian hipotesis (uji t). MRA dalam persamaan regresinya mengandung unsur interaksi (perkalian dua atau lebih variabel independen) dengan rumus persamaan sebagai berikut :

$Y=\alpha+\beta_{1} X_{1}+\beta_{2} X_{2}+\beta_{3} X_{3}+\beta_{4} X_{1} X_{3}+\beta_{5} X_{2} X_{3}+\varepsilon$

Keterangan:

Y : Nilai Perusahaan

$\alpha \quad$ : Konstanta

$\mathrm{X}_{1} \quad$ : Profitabilitas

$\mathrm{X}_{2}$ : Ukuran Perusahaan

$\mathrm{X}_{3}$ : Pengungkapan tanggung jawab sosial

$\mathrm{X}_{1} \mathrm{X}_{3}$ : Interaksi antara profitabilitas dengan pengungkapan tanggung jawab sosial

$\mathrm{X}_{2} \mathrm{X}_{3}$ : Interaksi antara ukuran perusahaan dengan pengungkapan tanggung jawab sosial

$\beta_{1-} \beta_{5}:$ Koefisien regresi

$\varepsilon \quad$ : Variabel pengganggu 


\section{HASIL DAN PEMBAHASAN}

Penelitian ini mencakup 11 perusahaan makanan dan minuman yang terdaftar di BEI. Jumlah data dalam penelitian ini sebanyak 11 perusahaan $\times 4$ tahun $=44$ pengamatan. Pengambilan sampel penelitian ini digambarkan pada Tabel $1 \mathrm{di}$ bawah ini.

Tabel 1.

Proses Penentuan Sampel Penelitian

\begin{tabular}{|c|c|}
\hline Kriteria & $\begin{array}{c}\text { Jumlah } \\
\text { Perusahaan }\end{array}$ \\
\hline $\begin{array}{l}\text { Populasi penelitian adalah perusahaan makanan dan minuman yang } \\
\text { terdaftar di Bursa Efek Indonesia tahun 2013-2016 }\end{array}$ & 14 \\
\hline $\begin{array}{l}\text { Jumlah perusahaan makanan dan minuman yang tidak } \\
\text { mempublikasikan laporan tahunan secara terus menerus selama } \\
\text { periode 2013-2016 }\end{array}$ & (1) \\
\hline $\begin{array}{l}2 \text { Jumlah perusahaan yang mengalami kerugian selama periode 2013- } \\
2016\end{array}$ & (2) \\
\hline Total sampel berdasarkan kriteria & 11 \\
\hline Tahun pengamatan & 4 \\
\hline Total sampel penelitian & 44 \\
\hline
\end{tabular}

Tabel 2.

Hasil Uji Statistik Deskriptif

\begin{tabular}{lrrrrr}
\hline & N & Minimum & Maximum & Mean & Std. Deviation \\
\hline Profitabilitas & 44 & .0225 & .6570 & .129403 & .1205493 \\
Ukuran Perusahaan & 44 & 11.4800 & 13.9630 & 12.546551 & .6833853 \\
Pengungkapan Tanggung & 44 & .0330 & .2857 & .148601 & .0778300 \\
Jawab Sosial & & & & & \\
Nilai Perusahaan & 44 & .70 & 14.63 & 3.3339 & 3.14659 \\
Valid N (listwise) & 44 & & & & \\
\hline Sumber: Data dion & & & &
\end{tabular}

Sumber: Data diolah, 2017

Hasil pengujian statistik deskriptif pada Tabel 2, nilai rata-rata variabel profitabilitas sebesar 0.129403 dengan standar deviasi sebesar 0.1205493 . Variabel profitabilitas memiliki nilai terendah (minimum) sebesar 0.0225 dimiliki oleh PT Sekar Bumi Tbk pada tahun 2016, sedangkan nilai tertinggi (maksimum) sebesar 0.6570 dimiliki oleh PT Multi Bintang Indonesia Tbk pada tahun 2013. Nilai rata-rata variabel ukuran perusahaan sebesar 12.546551 dengan standar 
Ni Kadek Dona Puspita Dewi dan I Made Mertha. Penungkapan...

deviasi sebesar 0.6833853 . Variabel ukuran perusahaan memiliki nilai terendah (minimum) sebesar 11.4800 dimiliki oleh PT Sekar Laut Tbk pada tahun 2013, sedangkan nilai tertinggi (maksimum) sebesar 13.9630 dimiliki oleh PT Indofood Sukses Makmur Tbk pada tahun 2015. Nilai rata-rata variabel pengungkapan tanggung jawab sosial sebesar 0.148601 dengan standar deviasi sebesar 0.0778300. Variabel pengungkapan tanggung jawab sosial memiliki nilai terendah (minimum) sebesar 0.0330 dimiliki oleh PT Multi Bintang Indonesia Tbk pada tahun 2013 dan PT Sekar Laut Tbk pada tahun 2013, sedangkan nilai tertinggi (maksimum) sebesar 0.2857 dimiliki oleh PT Indofood Sukses Makmur Tbk pada tahun 2016. Nilai rata-rata variabel pengungkapan tanggung jawab sosial sebesar 3.3339 dengan standar deviasi sebesar 3.14659. Variabel pengungkapan tanggung jawab sosial memiliki nilai terendah (minimum) sebesar 0.70 dimiliki oleh PT Wilmar Cahaya Indonesia Tbk pada tahun 2015, sedangkan nilai tertinggi (maksimum) sebesar 14.63 dimiliki oleh PT Multi Bintang Indonesia Tbk pada tahun 2013.

Tabel 3.

Hasil Uji Normalitas

\begin{tabular}{llr}
\hline & & Unstandardized Residual \\
\hline $\mathrm{N}$ & & 44 \\
Normal Parameters & Mean & .0000000 \\
& Std. Deviation & .77952239 \\
Most Extreme Differences & Absolute & .065 \\
& Positive & .053 \\
Kolmogorov-Smirnov Z & Negative & -.065 \\
Asymp. Sig. (2-tailed) & & .431 \\
Sumber: Data diolah, 2017 & & .992 \\
\hline
\end{tabular}


Berdasarkan hasil uji normalitas pada Tabel 3, diperoleh nilai Asymp. Sig. (2-tailed) sebesar 0,992 yang lebih besar dari 0,05, dimana artinya data pada model regresi yang digunakan dalam penelitian berdistribusi normal.

Tabel 4.

Hasil Uji Multikolinearitas

\begin{tabular}{llrr}
\hline Model & \multicolumn{2}{c}{ Collinearity Statistics } \\
& & Tolerance & \multicolumn{1}{c}{ VIF } \\
\hline 1 & Profitabilitas & .367 & 2.726 \\
& Ukuran Perusahaan & .228 & 4.380 \\
& Interaksi antara Profitabilitas dan Pengungkapan Tanggung & .239 & 4.192 \\
$\quad$ Jawab Sosial & & \\
$\quad$ Interaksi antara Ukuran Perusahaan dan Pengungkapan & .144 & 6.934 \\
$\quad$ Tanggung Jawab Sosial & &
\end{tabular}

Tabel 4 menunjukkan nilai tolerance $>0,10$ dan nilai $\mathrm{VIF}<10$ untuk semua variabel independen, maka dapat disimpulkan tidak adanya multikolinearitas antar variabel independen pada model regresi.

\section{Tabel 5.}

\section{Hasil Uji Autokorelasi}

\begin{tabular}{|c|c|c|c|c|c|}
\hline Model & $\mathbf{R}$ & R Square & $\begin{array}{l}\text { Adjusted R } \\
\text { Square }\end{array}$ & $\begin{array}{l}\text { Std. Error of } \\
\text { the Estimate }\end{array}$ & $\begin{array}{l}\text { Durbin- } \\
\text { Watson }\end{array}$ \\
\hline 1 & $969^{\mathrm{a}}$ & .939 & .931 & .82922 & 1.794 \\
\hline
\end{tabular}

Sumber: Data diolah, 2017

Berdasarkan Tabel 5, dapat dilihat bahwa hasil uji autokorelasi menunjukkan nilai Durbin-Watson sebesar 1,794 dengan nilai $\mathrm{d}_{\mathrm{L}}=1,28$ dan $\mathrm{d}_{\mathrm{U}}=$ 1,78 sehingga $4-\mathrm{d}_{\mathrm{L}}=2,72$ dan $4-\mathrm{d}_{\mathrm{U}}=2,22$. Nilai $d$-statistic berada di antara $\mathrm{d}_{\mathrm{U}} \mathrm{dan}$ $4-\mathrm{d}_{\mathrm{U}}(1,78<1,794<2,22)$ artinya model regresi tidak mengandung gejala autokorelasi. 
Tabel 6.

Hasil Uji Heteroskedastisitas

\begin{tabular}{|c|c|c|c|c|c|c|}
\hline \multirow{2}{*}{\multicolumn{2}{|c|}{ Model }} & \multicolumn{2}{|c|}{$\begin{array}{l}\text { Unstandardized } \\
\text { Coefficients }\end{array}$} & \multirow{2}{*}{$\begin{array}{c}\text { Standardized } \\
\text { Coefficients }\end{array}$} & \multirow[t]{2}{*}{$\mathbf{t}$} & \multirow[t]{2}{*}{ Sig. } \\
\hline & & B & $\begin{array}{l}\text { Std. } \\
\text { Error }\end{array}$ & & & \\
\hline \multirow[t]{6}{*}{1} & (Constant) & .452 & 2.048 & & .221 & .827 \\
\hline & Profitabilitas & 1.236 & .888 & .296 & 1.392 & .172 \\
\hline & Ukuran Perusahan & .023 & .178 & .031 & .129 & .898 \\
\hline & $\begin{array}{l}\text { Pengungkapan Tanggung } \\
\text { Jawab Sosial }\end{array}$ & -1.703 & 1.688 & -.264 & -1.009 & .320 \\
\hline & $\begin{array}{l}\text { Interaksi antara Profitabilitas } \\
\text { dan Pengungkapan Tanggung } \\
\text { Jawab Sosial }\end{array}$ & .095 & .155 & .475 & .615 & .542 \\
\hline & $\begin{array}{l}\text { Interaksi antara Ukuran } \\
\text { Perusahaan dan Pengungkapan } \\
\text { Tanggung Jawab Sosial }\end{array}$ & -.004 & .005 & -.575 & -.746 & .460 \\
\hline
\end{tabular}

Nilai Sig. pada Tabel 6 menunjukkan masing-masing variabel bebas sebesar 0,$172 ; 0,898 ; 0,320,0,542$ dan 0,460 . Nilai tersebut lebih besar dari tingkat signifikansi 0,05 yang artinya tidak terdapat pengaruh antara variabel bebas terhadap absolute residual, sehingga model yang dibuat tidak mengandung gejala heteroskedastisitas.

Model analisis data yang digunakan dalam penelitian ini adalah Moderated Regression Analysis (MRA) yang bertujuan untuk mengetahui pengaruh profitabilitas dan ukuran perusahaan pada nilai perusahaan dengan pengungkapan tanggung jawab sosial sebagai variabel moderasi di perusahaan makanan dan minuman yang terdaftar di Bursa Efek Indonesia tahun 2013-2016. Hasil moderated regression analysis dalam penelitian ini dapat dilihat pada Tabel 7. 
Tabel 7.

Hasil Moderated Regression Analysis (MRA)

\begin{tabular}{|c|c|c|c|c|c|}
\hline \multirow[t]{2}{*}{ Model } & \multicolumn{2}{|c|}{$\begin{array}{c}\text { Unstandardized } \\
\text { Coefficients } \\
\end{array}$} & \multirow{2}{*}{$\frac{\begin{array}{c}\text { Standardized } \\
\text { Coefficients }\end{array}}{\text { Beta }}$} & \multirow[t]{2}{*}{$\mathbf{t}$} & \multirow[t]{2}{*}{ Sig. } \\
\hline & B & $\begin{array}{l}\text { Std. } \\
\text { Error }\end{array}$ & & & \\
\hline 1 (Constant) & -12.197 & 3.502 & & -3.483 & .001 \\
\hline Profitabilitas & 20.633 & 1.518 & .790 & 13.591 & .000 \\
\hline Ukuran Perusahaan & 1.113 & .304 & .242 & 3.665 & .001 \\
\hline $\begin{array}{l}\text { Pengungkapan Tanggung } \\
\text { Jawab Sosial }\end{array}$ & -12.953 & 2.887 & -.320 & -4.487 & .000 \\
\hline $\begin{array}{l}\text { Interaksi antara } \\
\text { Profitabilitas dan } \\
\text { Pengungkapan Tanggung } \\
\text { Jawab Sosial }\end{array}$ & -1.251 & .265 & -.997 & -4.721 & .000 \\
\hline $\begin{array}{l}\text { Interaksi antara Ukuran } \\
\text { Perusahaan dan } \\
\text { Pengungkapan Tanggung } \\
\text { Jawab Sosial } \\
\end{array}$ & .055 & .009 & 1.263 & 5.997 & .000 \\
\hline $\mathrm{R}^{2}$ & & & & & 0,939 \\
\hline Adjusted $\mathrm{R}^{2}$ & & & & & 0,931 \\
\hline F Statistik & & & & & 116,233 \\
\hline F Signifikansi & & & & & 0,000 \\
\hline
\end{tabular}

Sumber: Data diolah, 2017

Berdasarkan hasil analisis seperti yang disajikan pada Tabel 7, maka persamaan Moderated Regression Analysis adalah sebagai berikut:

$Y=-12,197+0,790 X_{1}+0,242 X_{2}-0,320 X_{3}-0,997 X_{1} X_{3}+1,263 X_{2} X_{3}+\varepsilon$

Nilai konstanta sebesar -12,197 memiliki arti apabila variabel independen profitabilitas, ukuran perusahaan, pengungkapan tanggung jawab sosial, interaksi profitabilitas dengan pengungkapan tanggung jawab sosial dan interaksi ukuran perusahaan dengan pengungkapan tanggung jawab sosial bernilai konstan, maka variabel dependen nilai perusahaan akan menurun sebesar 12,197. Variabel profitabilitas $\left(\mathrm{X}_{1}\right)$ memiliki koefisien regresi $\left(\beta_{1}\right)$ sebesar 0,790 . Koefisien regresi variabel profitabilitas bernilai positif menunjukkan adanya hubungan searah antara variabel independen profitabilitas dengan variabel dependen nilai 
Ni Kadek Dona Puspita Dewi dan I Made Mertha. Penungkapan...

perusahaan, artinya apabila nilai profitabilitas meningkat 1 satuan dapat meningkatkan nilai perusahaan sebesar 0,790 dengan asumsi variabel independen yang lain bernilai konstan. Variabel ukuran perusahaan $\left(\mathrm{X}_{2}\right)$ memiliki koefisien regresi $\left(\beta_{2}\right)$ sebesar 0,242 . Koefisien regresi variabel ukuran perusahaan bernilai positif menunjukkan adanya hubungan searah antara variabel independen ukuran perusahaan dengan variabel dependen nilai perusahaan, artinya apabila nilai ukuran perusahaan meningkat 1 satuan akan menyebabkan nilai perusahaan meningkat sebesar 0,242 dengan asumsi variabel independen yang lain bernilai konstan. Variabel pengungkapan tanggung jawab sosial $\left(\mathrm{X}_{3}\right)$ memiliki koefisien regresi $\left(\beta_{3}\right)$ sebesar $-0,320$. Koefisien regresi variabel pengungkapan tanggung jawab sosial bernilai negatif menunjukkan adanya hubungan tidak searah antara variabel pengungkapan tanggung jawab sosial dengan variabel dependen nilai perusahaan, artinya jika nilai pengungkapan tanggung jawab sosial meningkat 1 satuan menyebabkan nilai perusahaan menurun sebesar 0,320 dengan asumsi variabel independen yang lain bernilai konstan. Interaksi antara variabel profitabilitas dengan variabel pengungkapan tanggung jawab sosial $\left(\mathrm{X}_{1} \mathrm{X}_{3}\right)$ memiliki koefisien moderasi $\left(\beta_{4}\right)$ sebesar - 0,997, artinya efek moderasi yang diberikan adalah negatif. Artinya apabila moderasi pengungkapan tanggung jawab sosial meningkat 1 satuan maka pengaruh profitabilitas pada nilai perusahaan menurun sebesar 0,997 dengan asumsi variabel independen yang lain bernilai konstan. Interaksi antara variabel ukuran perusahaan dengan variabel pengungkapan tanggung jawab sosial $\left(\mathrm{X}_{2} \mathrm{X}_{3}\right)$ memiliki koefisien moderasi $\left(\beta_{5}\right)$ sebesar 1,263, artinya efek moderasi yang diberikan adalah positif. Artinya 
apabila moderasi pengungkapan tanggung jawab sosial meningkat 1 satuan maka pengaruh positif ukuran perusahaan pada nilai perusahaan meningkat sebesar 1,263 dengan asumsi variabel independen yang lain bernilai konstan.

Pada Tabel 7 dapat dilihat bahwa nilai adjusted $\mathrm{R}^{2}$ adalah sebesar 0,931, mempunyai arti bahwa $93,1 \%$ variansi dari variabel dependen, yaitu nilai perusahaan mampu dijelaskan oleh variansi variabel independen, yaitu profitabilitas, ukuran perusahaan, pengungkapan tanggung jawab sosial, interaksi antara profitabilitas dan pengungkapan tanggung jawab sosial, serta interaksi antara ukuran perusahaan dan pengungkapan tanggung jawab sosial, sedangkan sisanya sebesar $6,9 \%$ dijelaskan oleh faktor lainnya di luar persamaan regresi. Pada Tabel 7 dapat dilihat hasil analisis uji F, tingkat signifikan $(\alpha)$ sebesar 5 persen atau 0,05 menunjukkan nilai $\mathrm{F}$ hitung sebesar 116.233 dan nilai signifikansi $\mathrm{F}$ atau $p$-value sebesar 0,000 lebih kecil dari $\alpha=0,05$. Hasil menunjukkan jika semua variabel mampu menjelaskan nilai perusahaan.

Pada Tabel 7 dapat dilihat hasil uji hipotesis bahwa profitabilitas berpengaruh positif dan signifikan pada nilai perusahaan. Hasil penelitian menunjukkan nilai koefisien regresi variabel profitabilitas sebesar 13,591 dengan nilai signifikansi sebesar 0,000 dimana lebih kecil dari 0,05. Berdasarkan hasil penelitian tersebut menunjukkan bahwa profitabilitas yang diproksikan dengan ROA mampu memengaruhi keadaan perusahaan yang berdampak pada nilai perusahaan. Semakin besar profitabilitas suatu perusahaan, semakin besar tingkat keuntungan yang dicapai perusahaan dan semakin baik pula posisi perusahaan tersebut dari segi penggunaan aset. Profitabilitas dapat menunjukkan tingkat 
Ni Kadek Dona Puspita Dewi dan I Made Mertha. Penungkapan...

keuntungan bersih yang mampu diraih oleh perusahaan saat menjalankan operasinya, sehingga perusahaan yang memiliki profitabilitas yang tinggi akan dapat menarik minat investor untuk menanamkan modalnya di perusahaan tersebut, sehingga hal ini pada akhirnya akan dapat meningkatkan nilai perusahaan. Hasil penelitian ini didukung oleh penelitian yang dilakukan oleh Purwaningsih dan Wirajaya (2014) dan Widhiastuti dan Latrini (2015) yang menunjukkan bahwa profitabilitas berpengaruh terhadap nilai perusahaan sehingga ketika laba perusahaan naik maka nilai perusahaan akan ikut naik.

Hasil uji hipotesis pada Tabel 7 menunjukkan bahwa ukuran perusahaan berpengaruh positif dan signifikan pada nilai perusahaan. Nilai koefisien regresi untuk variabel ukuran perusahaan sebesar 3,665 dengan nilai signifikansi sebesar 0,001 dimana lebih kecil dari 0,05. Hal ini menunjukkan nilai perusahaan akan meningkat jika semakin besar ukuran perusahaan tersebut. Hasil penelitian yang dilakukan oleh Prasetyorini (2013) serta Kusumayanti dan Astika (2016) mendapatkan hasil jika ukuran perusahaan berpengaruh positif pada nilai perusahaan. Analisa (2011) menyatakan bahwa kondisi perusahaan besar cenderung lebih stabil. Hal ini akan berdampak pada peningkatan nilai harga saham perusahaan karena investor tertarik untuk menamankan modalnya.

Berdasarkan Tabel 7 dapat diketahui bahwa nilai signifikansi uji t untuk interaksi variabel profitabilitas dengan variabel pengungkapan tanggung jawab sosial adalah sebesar 0,000 yaitu lebih kecil dari 0,05 dengan koefisien regresi bernilai negatif sebesar -4.721 . Berdasarkan hal tersebut maka hipotesis ketiga $\left(\mathrm{H}_{3}\right)$ diterima. Nilai koefisien regresi negatif, berarti pengungkapan tanggung 
jawab sosial memperlemah pengaruh profitabilitas pada nilai perusahaan. Hasil ini sejalan dengan penelitian yang sudah dilakukan oleh Munaroh dan Priyadi (2014) yang menyatakan bahwa CSR memperlemah hubungan antara profitabilitas dan nilai perusahaan. Perusahaan dalam mengungkapkan tanggung jawab sosial memerlukan biaya yang tidak sedikit. Soana (2011) berpendapat dalam pengungkapan tanggung jawab sosial terdapat biaya tambahan yang signifikan dan akan menghilangkan peluang perolehan dividen oleh pemegang saham. Modigliani dan Miller (1963) berpendapat jika nilai perusahaan ditentukan oleh earning power dari aset perusahaan. Hasil penelitian yang negatif menunjukkan bahwa semakin kecil earning power menyebabkan semakin kecil profitabilitas yang diperoleh oleh perusahaan sehingga menurunkan nilai perusahaan.

Berdasarkan Tabel 7 dapat diketahui bahwa nilai signifikansi uji t untuk interaksi variabel ukuran perusahaan dengan variabel pengungkapan tanggung jawab sosial adalah sebesar 0,000 yaitu lebih kecil dari 0,05 dengan koefisien regresi bernilai positif sebesar 5.997. Nilai koefisien regresi positif, berarti pengungkapan tanggung jawab sosial memperkuat pengaruh ukuran perusahaan pada nilai perusahaan. Hasil penelitian ini didukung oleh hasil penelitian yang dilakukan oleh Imron dkk (2013). Semakin besar aset suatu perusahaan maka semakin luas aktivitas perusahaan tersebut. Oleh karena itu, semakin besar perusahaan akan semakin mampu melakukan pengungkapan program sosial demi citra yang baik di mata stakeholder. Gray et al., (1996) menyatakan bahwa kelangsungan hidup perusahaan tergantung pada dukungan stakeholder sehingga aktivitas perusahaan adalah untuk mencari dukungan tersebut karena dapat 
Ni Kadek Dona Puspita Dewi dan I Made Mertha. Penungkapan...

berpengaruh terhadap kelangsungan hidup perusahaan dan dapat meningkatkan nilai perusahaan.

Implikasi dari penelitian ini terdiri dari dua, yaitu implikasi teoretis dan implikasi praktis. Implikasi Teoretis dalam penelitian ini adalah ditemukan bahwa variabel independen yaitu profitabilitas dan ukuran berpengaruh signifikan pada nilai perusahaan. Sejalan dengan teori sinyal dimana tingginya profitabilitas perusahaan merupakan sebuah sinyal positif yang diberikan oleh perusahaan kepada investor sehingga akan dapat meningkatkan nilai perusahaan. Perusahaan besar cenderung memiliki kondisi yang lebih stabil sehingga menjadikannya sinyal positif bagi investor. Variabel moderasi yaitu pengungkapan tanggung jawab sosial memperlemah hubungan antara profitabilitas dengan nilai perusahaan. Hasil ini tidak sesuai dengan teori stakeholder yang berpandangan bahwa perusahaan harus melakukan pengungkapan sosial sebagai salah satu tanggung jawab kepada para stakeholder, sehingga nantinya pasar akan memberikan apresiasi yang positif. Hasil penelitian ini juga tidak sejalan dengan teori legitimasi, pengungkapan tanggung jawab sosial oleh perusahaan tidak direspon positif oleh stakeholder. Hal ini diduga karena biaya tambahan dapat mengurangi perluang perolehan laba perusahaan yang berdampak pada menurunnya nilai perusahaan. Pengungkapan tanggung jawab sosial memperkuat hubungan antara ukuran perusahaan dengan nilai perusahaan. sejalan dengan teori stakeholder dan teori legitimasi yaitu semakin besar perusahaan akan semakin berusaha untuk mengungkapkan program sosial yang baik untuk meningkatkan 
citra positif di stakeholder. Implikasi praktis penelitian ini adalah bagi investor dan perusahaan.

\section{SIMPULAN}

Berdasarkan hasil penelitian yang diperoleh melalui analisis data serta pembahasan seperti yang telah diuraikan pada bab sebelumnya, maka dapat disimpulkan bahwa profitabilitas yang diproksikan menggunakan ROA berpengaruh secara positif dan signifikan pada nilai perusahaan. Ukuran perusahaan yang dilihat dari total aset yang dimiliki perusahaan berpengaruh secara positif dan signifikan pada nilai perusahaan. Pengungkapan tanggung jawab sosial berpengaruh terhadap hubungan profitabilitas pada nilai perusahaan. Namun, pengungkapan tanggung jawab sosial memperlemah pengaruh profitabilitas pada nilai perusahaan. Pengungkapan tanggung jawab sosial berpengaruh terhadap hubungan ukuran perusahaan pada nilai perusahaan. Pengungkapan tanggung jawab sosial memperkuat pengaruh ukuran perusahaan pada nilai perusahaan. Saran yang dapat diberikan yaitu perusahaan sebaiknya mengelola aset dengan lebih efektif. Bagi investor sebaiknya mempertimbangkan profitabilitas dan ukuran perusahaan dalam mengambil keputusan investasi.

\section{REFERENSI}

Aghashahi, Betsabeh, Siti Zaleha, Majid Sarli, dan Abdollah Ah Mand. 2013. Corporate Social Responsibility Reporting of Food Industry Major Players. Interdisciplinary Journal of Contemporary Research in Business, 5(2), pp: 751-761.

Analisa, Yangs. (2011). Pengaruh Ukuran Perusahaan, Leverage, Profitabilitas dan Kebijakan Deviden Terhadap Nilai Perusahaan (Studi Pada Perusahaan Manufaktur Yang Terdaftar Di Bursa Efek Indonesia Tahun 2006-2008). Skripsi Akuntansi Fakultas Ekonomi Universitas Diponegoro. 
Ni Kadek Dona Puspita Dewi dan I Made Mertha. Penungkapan...

Armika, A.A. Ayu Mutya. 2017. Pengaruh Pengungkapan Tanggung Jawab Sosial pada Nilai Perusahaan dengan Profitabilitas sebagai Variabel Pemoderasi (Studi Empiris Perusahaan Industri Dasar dan Kimia yang Terdaftar di Bursa Efek Indonesia Tahun 2013-2015). Skripsi. Universitas Udayana.

Ayu, Dea Putri dan Suarjaya, A.A. Gede. 2017. Pengaruh Profitabilitas terhadap Nilai Perusahaan dengan Corporate Social Responsibility sebagai Variabel Mediasi pada Perusahaan Pertambangan. E-Jurnal Manajemen Universitas Udayana. 6(2), hal. 1112-1138.

Barkemeyer, Ralf. 2007. "Legitimacy as a Key Driver and Determinant of CSR in Developing Countries". Paper for the 2007 Marie Curie Summer School on Earth System Governance, 28 May-06 June 2007, Amsterdam.

Branco, Manuel Castelo and Rodrigues Lucia Lima. 2008. Faktors Influencing Social Responsibility Disclosure by Portuguese Companies. Journal of Business Ethies, 83, pp: 685-701.

Brigham, Eugene dan Houston Joel. 2007. Manajemen Keuangan. Jakarta: Erlangga.

Dwipayadnya, Putu Agus, Ni Luh Putu Wiagustini dan Ida Bgs. Anom Purbawangsa. 2015. Kepemilikan Manajerial dan Leverage sebagai Prediktor Profitabilitas dan Pengungkapan Corporate Social Responsibility. Jurnal Buletin Studi Ekonomi, 20(2), h:150-157.

Elliot, W. Brooke., Jackson, Kevin E., Peecher, Mark E., White, Brian J. 2011. Does Corporate Social Responsibility Performance Distort Investors Estimate Of Fundamental Value?. Departmen of Accountancy. University of Illionist at Urbana-Champaign.

Gamerschlag R, Moller K, Verbeeten F. 2011. Determinants of voluntary CSR disclosure: empirical evidence from Germany. Review of Managerial Science, 5, pp:233-262.

Ghozali, Imam. 2016. Aplikasi Analisis Multivariete dengan Program IBM SPSS 23. Cetakan ke 8. Semarang : Univertitas Diponegoro.

Gill, Amarjit, and Neil Mathur. 2011. Factors that Influence Financial Leverage of Canadian Firms. Journal of Applied Finance \& Banking, 1(2), pp:1937.

Gill, Amarjit. and Obradovich, John D. 2012. The Impact of Corporate Governance and Financial Leverage on the Value of American Firms. International Research Journal of Finance and Economics. 91.

Gray, et al., 1996, Accounting and Accountability: Changes and Challenges in Corporate Social and Environmental Reporting. Prentice Hall Europe, Hemel Hempstead. 
Guthrie, J., Petty, R., and Yongvanich, K. (2004), "Using content analysis as a research method to inquire into intellectual capital reporting".Journal of Intellectual Capital, 5(2), pp:282-293.

Haruman, Tendi. 2008. "Pengaruh Struktur Kepemilikan Terhadap Keputusan Keuangan dan Nilai Perusahaan". Simposium Nasional Akuntansi XI, Pontianak.

Imron, dkk. 2013. Pengaruh Kinerja Keuangan dan Ukuran Perusahaan Terhadap Nilai perusahaan Dengan Corporate Social Responsibility dan Good Corporate Governance Sebagai Variabel Moderasi. POTENSIO ISSN 1829-7978.18(2), hal.82-93.

Jogiyanto. 2013. Teori Portofolio dan Analisis Investasi. Edisi ketujuh. Yogyakarta: BPFE.

Kaur, Bhupinder. 2015. Impact of Corporate Social Responsibility on the Performance of the Companies. Journal for Studies in Management and Planning, 1(2).

Kusumayanti, Ni Ketut Ratna dan Astika, Ida Bagus Putra. 2016. Corporate Social Responsibility sebagai Pemediasi Pengaruh Ukuran Perusahaan, Profitabilitas dan Leverage pada Nilai Perusahaan. E-Jurnal Akuntansi Universitas Udayana, 15(1), hal.549-583.

Modigliani, F. dan M. H. Miller. (1963). 'Taxes and the Cost of Capital: A Correction". American Economic Review. 53, pp: 433-43.

Mukhtaruddin, Relasari, dan Messa Felmina. 2014. Good Corporate Governance Mechanism, Corporate Social Responsibility Disclosure on Firm Value: Empirical Study on Listed Company in Indonesia Stock Exchange. International Journal of Finance \& Accounting Studies, 2(1), pp:135-166.

Mulyadi, Martin Surya dan Yunita Anwar. 2012. Influence of Corporate Governance and Profitability to corporate CSR Disclosure. International Journal of Arts and Commerce, 1(7), pp: 29-35.

Munaroh, Aisyatul dan Priyadi, Maswar Patuh. 2014. Pengaruh Profitabilitas terhadap Nilai Perusahaan dengan Corporate Social Responsibilty sebagai Variabel Moderating. Jurnal Ilmu \& Riset Akuntansi Sekolah Tinggi Ilmu Ekonomi Indonesia Surabaya. 3(4).

Prasetyorini, Bhekti Fitri. 2013. Pengaruh Ukuran Perusahaan, Leverage, Price Earning Ratio dan Profitabilitas Terhadap Nilai Perusahaan. Jurnal Ilmu Manajemen, 1 (1), hal.183-196.

Pratiwi, Ni Putu Diah. 2017. Pengaruh Kebijakan Hutang dan profitabilitas pada Nilai Perusahaan dengan Kebijakan Dividen sebagai Variabel Pemoderasi 
Ni Kadek Dona Puspita Dewi dan I Made Mertha. Penungkapan...

(Studi pada Perusahaan Manufaktur yang terdaftar di Bursa efek Indonesia Tahun 2013-2015). Skripsi. Universitas Udayana.

Purwaningsih, Ni Kadek Irma dan Wirajaya, I Gde Ary. 2014. Pengaruh Kinerja pada Nilai Perusahaan dengan Corporate Social Responsibility sebagai Variabel Pemoderasi. Jurnal Akuntansi Universitas Udayana, 7(3), hal.598-613.

Raharja, Komang Adik Hari dan Putra, I Made Pande Dwiana. 2016. Risiko Kredit sebagai Pemoderasi Pengaruh Leverage dan Ukuran Perusahaan terhadap Nilai Perusahaan. E-Jurnal Akuntansi Universitas Udayana, 16(1), hal.645-674.

Ratih, I Dewa Ayu dan dan I Gusti Ayu Eka Damayanthi.2016. Kepemilikan Manajerial dan Profitabilitas pada Nilai Perusahaan Dengan Pengungkapan Tanggungjawab Sosial Sebagai Variabel Pemoderasi. EJurnal Akuntansi Universitas Udayana,14(2), hal.1510-1538.

Retno, Reny Dyah M., Priantinah, Denies. 2012. Pengaruh Good Corporate Governance Dan Pengungkapan Corporate Social ResponsibilityTerhadap Nilai Perusahaan(Studi Empiris Pada Perusahaan Yang TerdaftarDi Bursa Efek Indonesia Periode 2007-2010). Jurnal Fakultas Ekonomi Universitas Negeri Yogyakarta, 1(1).

Smithers, Andrew, and Stephen Wright. 2000. Valuing Wall Street: Protecting Wealth in Turbulent Market. New York: Mc Graw-Hill.

Soana, Maria Gaia. (2011). "The Relationship Between Corporate Social Performance and Corporate Financial Performance in the Banking Sector". Journal of Business Ethics. 104 (1), pp: 133-148.

Sujoko. dan Soebiantoro, Ugy. 2007. "Pengaruh Struktur Kepemilikan Saham, Leverage, Faktor Intern Dan Faktor Ekstern Terhadap Nilai Perusahaan”, Jurnal Manajemen dan Kewirausahaan, 9(1).

Susianti, Maria Ni Luh dan Gerianta Wirawan Yasa. 2013. Pengaruh Kinerja Keuangan terhadap Nilai Perusahaan dengan Pemoderasi Good Corporate Governance dan Corporate Social Resposibility. Jurnal Akuntansi Universitas Udayana, 3(1), hal.73-91.

Undang-Undang No.25 Tahun 2007 tentang Penanaman Modal.

Undang-undang Republik Indonesia Nomor 40 Tahun 2007 Tentang Perseroan Terbatas Pasal 74.

Wiagustini, Ni Luh Putu. 2010. Dasar-dasar Manajemen Keuangan. Denpasar : Udayana University Press. 
Widhiastuti, Ni Luh Putu dan Latrini, Made Yenni. 2015. Pengaruh Return On Asset dan Intangible Asset Terhadap Nilai Perusahaan dengan Corporate Social Responsibility sebagai Variabel Pemoderasi. E-Jurnal Akuntansi Universitas Udayana, 11(2), hal:370-383.

Yao, S., Wang, J., and Song, L. 2011. Determinants of Social Responsibility Disclosure by Chinesse Firms. Discussion Paper 72. Nottingham: The University of Nottingham. 